\title{
Diallyl sulfide inhibits PhIP-induced cell death via the inhibition of DNA strand breaks in normal human breast epithelial cells
}

\author{
AYOOLA ABOYADE-COLE, SELINA DARLING-REED, EBENEZER ORIAKU, \\ MICHAEL MCCASKILL and RONALD THOMAS \\ Environmental Toxicology Program, College of Pharmacy and Pharmaceutical \\ Sciences, Florida A\&M University, Tallahassee, FL 32307, USA
}

Received November 28, 2007; Accepted February 27, 2008

DOI: 10.3892/or_00000009

\begin{abstract}
Amino-1-methyl-6-phenylimidazo[4,5-b]pyridine (PhIP) is associated with mammary carcinomas in animals and humans. PhIP is metabolized by CYP $1 \mathrm{~A} 1 / 1 \mathrm{~A} 2$ and cytochrome b5 reductase, producing free radicals causing DNA strand breaks. Diallyl sulfide (DAS) prevents cancer in animals. We hypothesized that DAS will attenuate PhIPinduced DNA strand breaks and cell death. To test this hypothesis, we treated MCF-10A cells with PhIP, DAS and PhIP/DAS for 24, 48 and 72 h. DAS inhibited the PhIPinduced DNA strand breaks by $22 \%$ after $48 \mathrm{~h}$ and the strand breaks were completely inhibited at $72 \mathrm{~h}$. PhIP reduced cell viability at each time point. However, DAS only attenuated this reduction in cell viability by $56 \%$ at $72 \mathrm{~h}$. N-OH PhIP inhibited cell viability by $26 \%$ at $72 \mathrm{~h}$. DAS completely attenuated this reduction in cell viability and may prevent PhIP-induced breast cancer via alterations in DNA damage and cell viability.
\end{abstract}

\section{Introduction}

Diet is the second most preventable cause of cancer (1). Increase in well-done meat consumption is associated with an elevated risk of breast cancer (2). This correlation between increased cancer risk and meat preparation is most likely due to the production of high levels of heterocyclic amines (3). The heterocyclic amine most abundantly found in the human diet is 2-amino-1-methyl-6-phenylimidazo[4,5-b]pyridine (PhIP). $\mathrm{PhIP}$ has induced tumors in the prostate, colon and breast (3-5).

PhIP is oxidized by cytochrome P-450 1A2 (CYP1A2) to form an $\mathrm{N}$-hydroxy derivative. The $\mathrm{N}$-hydroxy derivative undergoes subsequent acetylation or sulphation, resulting in the formation of a nitrenium ion free radical that covalently binds to the $\mathrm{C} 8$ position of guanine residues. The resultant adduct is

Correspondence to: Dr Ronald Thomas, Environmental Toxicology Program, College of Pharmacy and Pharmaceutical Sciences, Florida A\&M University, Tallahassee, FL 32307, USA

E-mail: ronald.thomas@famu.edu

Key words: 2-amino-1-methyl-6-phenylimidazo[4,5-b]pyridine, diallyl sulfide, chemoprevention, cell viability, DNA strand breaks primarily responsible for $\mathrm{GC} \rightarrow \mathrm{TA}$ transversions and deleterious frameshift mutations of a guanine within a G-rich repetitive sequence (6). The development of these mutations are the basis for PhIP's genotoxic effects, which include chromosome aberrations, DNA damage, micronuclei and sister chromatid exchange $(7,8)$. A failure to repair these genomic anomalies can result in cancer, especially when they occur in tumor suppressors and proto-oncogenes.

The alkaline single cell electrophoresis (comet) assay can be used to detect DNA damage, particularly single and double strand breaks that may occur as a result of exposure to genotoxic agents, such as PhIP $(9,10)$. Under electrophoretic conditions, fragmented DNA migrates toward the anode producing a tail and giving the appearance of a comet. The amount of fragmented DNA directly correlates with the length of the tail and thus provides a quantitative assessment of DNA damage induced by a particular agent (11).

Diallyl sulfide (DAS) is a lipophilic organosulfur component of garlic that has been demonstrated to protect against chemically-induced carcinogenesis in vivo and in vitro (12). One mechanism by which DAS may exert its anticarcinogenic properties is through its ability to inhibit DNA damage. DAS has been demonstrated to inhibit N-nitrosodimethylamine (NDMA) and aflatoxin B1 (AFB1)-induced DNA strand breaks in the liver cells of Wistar rats $(13,14)$. Therefore, we propose that DAS attenuates PhIP-induced cell death via the inhibition of DNA strand breaks.

\section{Materials and methods}

Chemicals and reagents. Phenol-red free DMEM/F-12 1:1 mix basal media, horse serum, trypsin, penicillin/streptomycin, Ultrapure low melting point agarose and Ultrapure normal melting point agarose were obtained from Invitrogen (Carlsbad, CA). The epidermal growth factor was obtained from BD Biosciences (San Jose, CA). Dimethly-sulfoxide (DMSO), hydrocortisone, Triton X-100, PBS, NaOH, Trizma base, $\mathrm{NaCl}, \mathrm{Na}_{2}$ EDTA, diethylpyrocarbonate (DEPC), ethanol and DAS were all purchased from Sigma (St. Louis, MO). Fully-frosted microscope slides and cover slips were purchased from Fisher Scientific (Pittsburgh, PA). PhIP was purchased from Toronto Research Chemicals. N-hydroxy PhIP was purchased from the National Cancer Institute Chemical Carcinogen Repository, Midwest Research Institute (Kansas City, MO). 

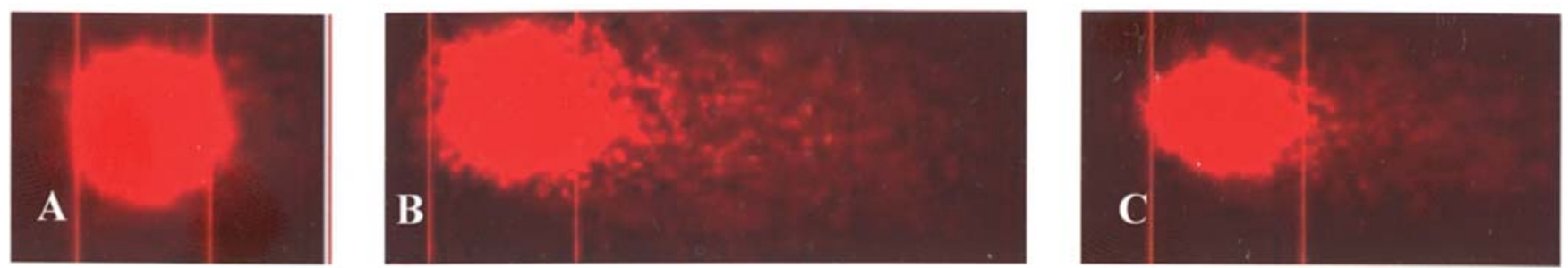

Figure 1. Inhibition of the formation of DNA strand breaks in PhIP-treated MCF-10A cells. (A) A cell is shown that was treated with $0.1 \%$ DMSO as a control. In this cell, there are no detectable DNA strand breaks as indicated by the absence of a comet tail. (B) A cell that was treated with PhIP (100 $\mu \mathrm{M})$ is shown. In this cell, the amount of DNA strand breaks was extensive as indicated by the large comet tail. (C) A cell is shown that was treated with PhIP and DAS, $100 \mu \mathrm{M}$ each. In this cell, DAS inhibited the PhIP-induced DNA strand breaks as indicated by the reduction in the size of the comet tail.

Cell culture. MCF-10A human breast epithelial cells were a gift from the laboratory of Dr Thomas Kocarek at Wayne State University (Detroit, MI). The cells were cultured in a humidified incubator at $37^{\circ} \mathrm{C}$ under $5 \% \mathrm{CO}_{2}$ atmospheric conditions in DMEM/F-12 1:1 mix basal media supplemented with $10 \mu \mathrm{g} / \mathrm{ml}$ insulin, $20 \mathrm{ng} / \mathrm{ml}$ epidermal growth factor, $0.5 \mu \mathrm{g} / \mathrm{ml}$ hydrocortisone, $5 \%$ horse serum and $1 \%$ penicillinstreptomycin $(10,000 \mathrm{U} / \mathrm{ml})$.

Cell treatment. MCF-10A human breast epithelial cells were plated and treated for 24,48 and $72 \mathrm{~h}$ with $\mathrm{PhIP}(100 \mu \mathrm{M})$, DAS $(100 \mu \mathrm{M})$ and $\mathrm{N}-\mathrm{OH} \mathrm{PhIP}(5 \mu \mathrm{M})$. These concentrations were chosen because PhIP $(100 \mu \mathrm{M})$ and N-OH PhIP $(1 \mu \mathrm{M})$ produced DNA adducts in MCF-10A cells after $24 \mathrm{~h}$ (15). Cells treated with combinations of PhIP/DAS and N-OH PhIP/DAS groups were pretreated with $100 \mu \mathrm{M}$ of DAS $6 \mathrm{~h}$ prior to dosing with PhIP $(100 \mu \mathrm{M})$ or N-OH PhIP $(5 \mu \mathrm{M})$. Untreated and DMSO treated cells served as negative and vehicle controls, respectively.

Comet assay. One million MCF-10A cells were treated as indicated above in T-25 $\mathrm{cm}^{2}$ culture flasks. At 24, 48 and $72 \mathrm{~h}$, the cells were trypsinized and centrifuged for $5 \mathrm{~min}$ at 1,000 rpm. The supernatant was discarded and the cell pellet was re-suspended in $500 \mu 1$ of $1 \mathrm{X} \mathrm{Ca}^{2+} / \mathrm{Mg}^{2+}$ free PBS. A $100 \mu \mathrm{l}$ aliquot of the treated cell suspensions was added to $900 \mu \mathrm{l}$ of low melting point agarose $(0.75 \%)$. Three slides were made of each sample by adding a $100 \mu \mathrm{l}$ aliquot of the cell/agarose mixture to the top of microscope slides precoated with a normal melting point agarose. The slides were solidified on ice and then placed in the refrigerator in icecold lysis buffer ( $\mathrm{pH} 10)$ containing $1 \%$ Triton $\mathrm{X}-100$ for $1 \mathrm{~h}$.

After lysing, the slides were placed in alkaline electrophoresis buffer $(\mathrm{pH}>13.5)$ for $30 \mathrm{~min}$ to allow the DNA to unwind and electrophoresed at $280 \mathrm{Amps} / 25 \mathrm{~V}$ for $30 \mathrm{~min}$. Following electrophoresis, the slides were washed three times with neutralization buffer (Tris buffer, $\mathrm{pH} 7.5$ ) and dehydrated for 5 min with $100 \%$ ethanol. The slides were stained with $100 \mu \mathrm{l}$ of propidium iodide $(20 \mu \mathrm{g} / \mathrm{ml})$ and examined under a fluorescent microscope. A total of 150 cell images were examined per slide under $20 \mathrm{X}$ magnification using the Kinetic Imaging comet assay software. The mean olive tail moment was used as a parameter for DNA fragmentation. Statistical analysis was performed using one-way analysis of variance and the Tukey multiple comparison test to determine significant differences amongst the treatment groups.
Cell viability. Cell viability was assessed using the CellTiter $96^{\circledR}$ AQueousOne solution cell proliferation assay. Ten thousand cells were plated per well in 96-well plates and treated as described above. At 24, 48 and 72 h, a $20 \mu 1$ aliquot of AqueousOne Solution (Promega Corporation, Madison, WI) was added to each well and incubated at $37^{\circ} \mathrm{C}$ for $2 \mathrm{~h}$ to allow color development. The plates were analyzed on a Bio-Tek Ex800 microplate reader using $\mathrm{KC}$ Junior software, where the absorbance at $480 \mathrm{~nm}$ was determined for each well. In this colorimetric assay, viable cells convert the MTS tetrazolium compound to a formazan product soluble in culture media. The amount of formazan product formed is directly proportional to the number of living cells in the culture.

Statistical analysis. Results are expressed as means \pm S.E.M. from a minimum of three independent experiments. Data were analyzed by one-way analysis of variance (ANOVA) and the Tukey multiple comparison test to determine significant differences $(\mathrm{P}<0.05)$ among the treatment groups.

\section{Results}

Alkaline single cell gel electrophoresis (comet assay). The ability of DAS to inhibit PhIP and N-OH PhIP induced DNA strand breaks in MCF-10A human breast epithelial cells was determined using the comet assay. The comet assay is frequently used to detect DNA strand breaks in individual cells. The mean olive tail moment or simply tail moment is used because it incorporates the amount of DNA that has been damaged with the size of the strands. Tail moment is defined as the product of the tail length and the fraction of total DNA in the tail. Tail moment incorporates a measure of the smallest detectable size of migrating DNA (reflected in the comet tail length) and the number of relaxed/broken pieces; represented by the intensity of DNA in the tail (16). Cells were treated with PhIP $(100 \mu \mathrm{M}), \mathrm{N}-\mathrm{OH}$ PhIP $(5 \mu \mathrm{M})$ and/or DAS $(100 \mu \mathrm{M})$ for 24,48 and 72 h. Fig. 1 illustrates DNA strand breaks induced by PhIP and the inhibition of these strand breaks by DAS. Individual cells with no DNA strand breaks appear as spheres with no tail. However, the cells that contain DNA damage appear as spheres with tails that resemble comets. PhIP-treated cells displayed a significant increase in DNA strand breaks over that of the control at $24 \mathrm{~h} 1.4$ and 0.9 , respectively. The DNA strand breaks that were produced after $24 \mathrm{~h}$ were apparently repaired after 48 and $72 \mathrm{~h}$ (Fig. 2) Treatment with DAS $(100 \mu \mathrm{M})$ showed no significant changes 


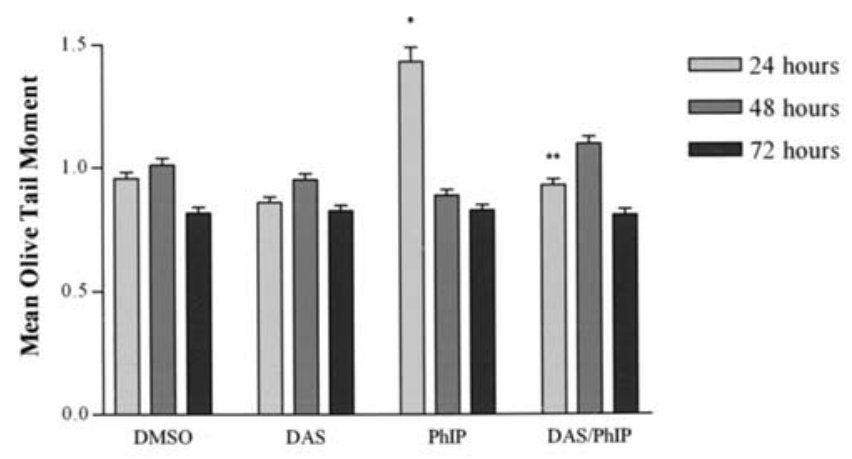

Figure 2. The inhibition of PhIP-induced DNA strand breaks by DAS at 24, 48 and $72 \mathrm{~h}$. MCF-10A cells were treated, harvested and analyzed as described in Materials and methods. Each bar on the graph represents the mean olive tail moment \pm S.E.M. of three independent experiments. *Data significantly different from the DMSO treatment group $(\mathrm{P}<0.05)$. ${ }^{* *}$ Data significantly different from the PhIP treatment group $(\mathrm{P}<0.05)$.

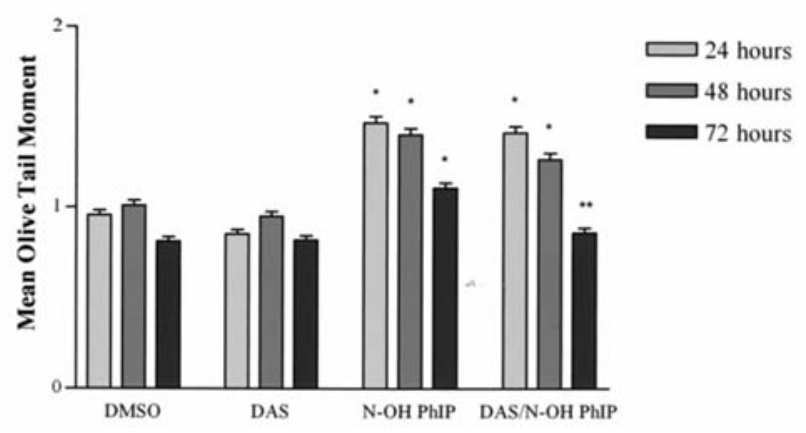

Figure 3. The inhibition of N-OH PhIP-induced DNA strand breaks by DAS at 24, 48 and $72 \mathrm{~h}$. MCF-10A cells were treated, harvested and analyzed as described in Materials and methods. Each bar on the graph represents the mean olive tail moment \pm S.E.M. of three independent experiments. ${ }^{*}$ Data significantly different from the DMSO treatment group $(\mathrm{P}<0.05)$. ${ }^{* *}$ Data significantly different from the N-OH PhIP treatment group $(\mathrm{P}<0.01)$.

in the production of DNA strand breaks from that of the negative and vehicle controls at any time point. However, pretreatment with DAS significantly reduced PhIP-induced DNA strand breaks to baseline levels after $24 \mathrm{~h}$. N-OH PhIP produced significant levels of DNA strand breaks at 24, 48 and $72 \mathrm{~h}$ having mean olive tail moments of $1.47,1.40$ and 1.11 , respectively (Fig. 3). Pretreatment with DAS inhibited this DNA damage at 24,48 and $72 \mathrm{~h}$ by decreasing mean olive tail moments to $1.41,1.27$ and 0.86 , respectively. DAS completely inhibited the N-OH PhIP-induced DNA strand breaks by $72 \mathrm{~h}$. This suggests that DAS does have an inhibitory effect on PhIP and N-OH PhIP-induced DNA strand breaks in human breast epithelial cells.

Cell viability. The effect of PhIP and $\mathrm{N}-\mathrm{OH}$ PhIP on the viability of MCF-10A cells was evaluated using the MTS assay. After PhIP treatment for 24, 48 and $72 \mathrm{~h}$, cell viability was reduced to 70, 70 and 64, respectively. Pre-treatment with DAS $(100 \mu \mathrm{M})$ attenuated a reduction in cell viability at 48 and $72 \mathrm{~h}$ resulting in cell viabilities of 72 and $84 \%$, respectively (Fig. 4). Cells treated with DAS alone showed no significant

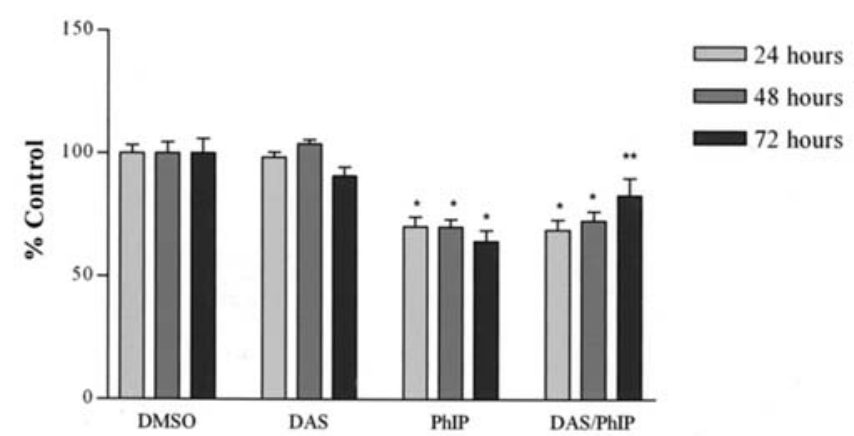

Figure 4. The attenuation of PhIP-induced growth arrest by DAS at 24, 48 and $72 \mathrm{~h}$. Cells were treated, harvested and analyzed as described in Materials and methods. Each bar on the graph represents the mean percentage of viable cells \pm S.E.M. of three independent experiments. *Data significantly different from the DMSO treatment group $(\mathrm{P}<0.05)$. ${ }^{* *}$ Data significantly different from the PhIP treatment group $(\mathrm{P}<0.01)$.

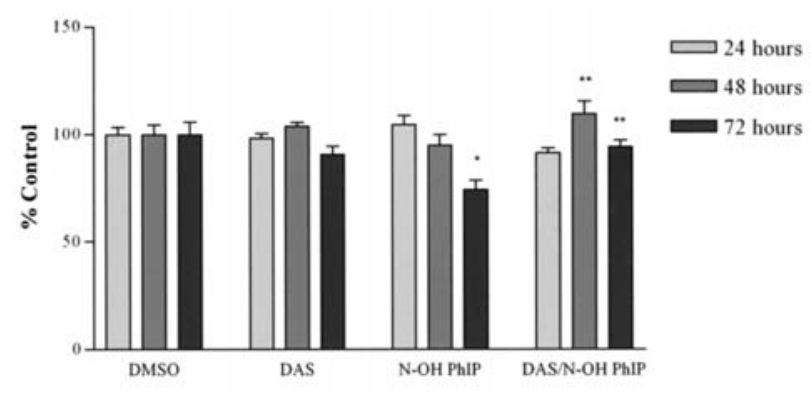

Figure 5. The attenuation of N-OH PhIP-induced growth arrest by DAS at 24, 48 and $72 \mathrm{~h}$. Cells were treated, harvested and analyzed as described in Materials and methods. Each bar on the graph represents the mean percentage of viable cells \pm S.E.M. of three independent experiments. *Data significantly different from the DMSO treatment group $(\mathrm{P}<0.05)$. ${ }^{* *}$ Data significantly different from the $\mathrm{N}-\mathrm{OH} \mathrm{PhIP}$ treatment group $(\mathrm{P}<0.01)$.

changes from the control at any time point. This suggests that DAS significantly inhibited PhIP-induced reductions in viability at $72 \mathrm{~h}$. Unlike $\mathrm{PhIP}, \mathrm{N}-\mathrm{OH} \mathrm{PhIP}$ only showed a significant reduction in cell viability at $72 \mathrm{~h}$. After $72 \mathrm{~h}, \mathrm{~N}-\mathrm{OH}$ PhIP reduced cell viability to $74 \%$. DAS attenuated this reduction in cell viability resulting in cell viability of $94 \%$ (Fig. 5). These results suggest that the inhibitory effects of DAS on PhIP and N-OH PhIP-induced cytotoxicity in human breast epithelial cells may require $72 \mathrm{~h}$ to manifest.

\section{Discussion}

The breast has been identified as a target for PhIP-induced carcinogenesis, DNA adduct formation and mutagenesis in animals as well as humans $(3,4,17-19)$. Furthermore, the positive correlation between red meat consumption and breast cancer demonstrated in epidemiological studies support the hypothesis that PhIP plays a role in the etiology of breast cancer (2). Studies have shown that the breast possesses sufficient enzymatic machinery to support PhIP bioactivation and generate DNA damage $(15,20)$, thereby identifying a need for further investigation into the genotoxic effects of PhIP 
and its metabolites. While much research has been performed on the production of DNA adducts, there is minimal information available on the production of PhIP-induced DNA strand breaks in breast epithelial cells.

One proposed mechanism by which PhIP produces strand breaks is through the production of reactive oxygen species during its metabolism. An imbalance in the production/ detoxification of reactive oxygen species results in oxidative stress, which is a known mediator of cancer. While the oxidative mechanisms of cancer have yet to be fully elucidated, DNA mutation as a result of oxidative damage and alterations in cell signaling pathways that control gene expression are postulated to cause cancer $(21,23)$. We have demonstrated in previous studies a significant dose-dependent increase in lipid peroxide formation following PhIP treatment via the induction of Phase I metabolizing enzymes cytochrome P4501A1 and 1A2 (CYP1A1 and CYP1A2) (15). Therefore, this generation of lipid peroxides correlates to the production of reactive PhIP metabolites. This increase in free radicals explains the production of PhIP-induced DNA strand breaks observed at the $24 \mathrm{~h}$ time point in this study. Over the course of time, $\mathrm{PhIP}$-induced strand breaks return to baseline levels presumably as a result of DNA repair.

$\mathrm{N}-\mathrm{OH}$ PhIP is a metabolite of PhIP that can be further metabolized into DNA binding mutagens by a number of phase II enzyme systems (24-26). During its metabolism, $\mathrm{N}-\mathrm{OH} \mathrm{PhIP}$ has been shown to produce free radicals and DNA adducts (27). Unlike PhIP, the DNA strand breaks caused by $\mathrm{N}-\mathrm{OH}$ PhIP persisted throughout the length of the study and had no significant effect on cell viability until $72 \mathrm{~h}$. This indicates that the cells remained viable with obvious damage, which is believed to be a mechanism for cancer induction.

Cell viability in PhIP-treated cells was significantly reduced at 24, 48 and $72 \mathrm{~h}$, even after DNA strand breaks returned to baseline levels. We demonstrated that PhIP $(100 \mu \mathrm{M})$ generated DNA adducts at the same time points and under similar conditions employed in this study (15). Therefore, the production of DNA adducts may be responsible for the reduced cell viability after the level of DNA strand breaks returned to baseline levels. We propose that the cells were arrested in an attempt to repair the DNA adducts, which would result in a fewer number of viable cells if the other treatment groups continued to proliferate normally. This proposition is substantiated by the research conducted by Creton et al (28) in which PhIP-treated MCF-10A cells displayed a substantial reduction in cell numbers not associated with cytotoxicity. Under normal circumstances, cells respond to genotoxicity through the propagation of cellular defense mechanisms that attempt to mitigate genomic injury (29). Failure to repair DNA adducts should result in cell death. However, those cells that evade repair and death have the potential to cause breast cancer $(19,30)$.

DAS is a garlic organosulfur compound that reduces chemically-induced genotoxicity and DNA damage $(31,32)$. Pretreatment with DAS was able to inhibit PhIP-induced damage at $24 \mathrm{~h}$. However, cell viability remained significantly reduced up until $72 \mathrm{~h}$. We propose that DAS inhibited cell growth until the damage could be repaired, presumably by $72 \mathrm{~h}$ when cell viability was restored to baseline levels. DAS also attenuated N-OH PhIP DNA damage and reduction of cell viability at $72 \mathrm{~h}$. The data are in agreement with research reviewed by Shukla and Kalra (12), where DAS was shown to enhance SOD activity and reduce cell proliferation of Hep$\mathrm{G}_{2}$ cells. The induction of SOD could explain the mechanism by which DAS inhibits DNA strand breaks.

We presented herein novel evidence that DAS inhibits PhIP and N-OH PhIP-induced DNA strand breaks and attenuates cell viability in MCF-10A human breast epithelial cells. DAS may be used as a chemopreventive agent based on its ability to inhibit DNA damage induced by heterocyclic amines. Further research is needed to fully elucidate the mechanisms by which DAS exerts these anticarcinogenic properties.

\section{Acknowledgements}

This study was funded in part by NIH Programs RCMI \# G12RR-03020 and 1C06RR012512-01.

\section{References}

1. World Health Organization. Cancer: diet and physical activity's impact. http://www.who.int/dietphysicalactivity/publications/ facts/cancer/en/ (Accessed May 2005).

2. Zheng W, Gustafson DR, Sinha R, Cerhan JR, Moore D, Hong CP, Anderson KE, Kushi LH, Sellers TA and Folsom AR: Well-done meat intake and the risk of breast cancer. J Natl Cancer Inst 90: 4320-4324,1998.

3. Nagao M, Ushijima T, Wakabayashi K, Ochiai M, Kushida H, Sugimura T, Hasegawa R, Shirai T and Ito N: Dietary carcinogens and mammary carcinogenesis. Induction of rat mammary carcinomas by administration of heterocyclic amines in cooked foods. Cancer 74: 1063-1069, 1994.

4. Ito N, Hasegawa R, Sano M, Tamano S, Esumi H, Takayama S and Sugimura T: A new colon and mammary carcinogen in cooked food, 2-amino-1-methyl-6-phenylimidazo[4,5-b]pyridine (PhIP). Carcinogenesis 12: 1503-1506, 1991.

5. Shirai T, Sano M, Tamano S, Takahashi M, Hirose M, Futakuchi M, Hasegawa R, Imaida K, Matsumoto K, Wakabayashi K, Sugimura T and Ito N: The prostate: a target for carcinogenicity of 2-amino-1-methyl-6-phenylimidazo[4,5-b] pyridine (PhIP) derived from cooked foods. Cancer Res 57: 195-198, 1997.

6. Gooderham N, Zhu H, Lauber S, Boyce A and Creton S: Molecular and genetic toxicology of 2-hydroxyamino-1-methyl6-phenylimidazo[4,5-b]pyridine (PhIP). Mutat Res 506-507: 91-99, 2002.

7. Otsuka C, Miura K, Satoh T, Hatanaka M, Wakabayashi K and Ishidate M: Cytogenic effects of a food mutagen, 2-amino-1methyl-6-phenylimidazo[4,5-b]pyridine (PhIP) and its metabolite 2-hydroxyamino-1-methyl-6-phenylimidazo[4,5-b]pyridine (N$\mathrm{OH} \mathrm{PhIP}$ ) on human and Chinese hamster cells in vitro. Mutat Res 359: 115-121, 1996.

8. Wu R, Tucker J, Sorenson K, Thompson L and Felton J: Differential effect of acetyltransferase expression on the genotoxicity of heterocyclic amines in CHO cells. Mutat Res 390: 93-103, 1997.

9. Ostling $\mathrm{O}$ and Johanson K: Microelectrophoretic study of radiation induced DNA damages in individual mammalian cells. Biochem Biophys Res Commun 123: 291-298, 1984.

10. Singh N, Stephens R and Schneider E: A simple technique for quantitation of low levels of DNA damage in individual cells. Exp Cell Res 175: 184-191, 1988.

11. Tice R, Agurell E, Anderson D, Burlinson B, Hartmann A, Kobayashi H, Miyamae Y, Rojas E, Ryu J and Sasaki Y: Single cell gel/comet assay: guidelines for in vitro and in vivo genetic toxicology testing. Environ Mol Mutagen 35: 206-221, 2000.

12. Shukla Y and Kalra N: Mini review: Cancer chemoprevention with garlic and its constitutents. Cancer Lett 247: 167-181, 2007.

13. Le Bon AM, Roy C, Dupont $\mathrm{C}$ and Suschetet $\mathrm{M}$ : In vivo genotoxic effects of dietary allyl sulfides in the rat. Cancer Lett 114: 131-134, 1997 . 
14. Guyonnet D, Belloir C, Suschetet M, Siess M and Le Bon A: Mechanisms of protection against aflatoxin $\mathrm{B}(1)$ genotoxicity in rats treated by organosulfur compounds from garlic. Carcinogenesis 23: 1335-1341, 2002.

15. Thomas R, Green M, Wilson C, Weckle A, Duanmu Z, Kocarek T and Runge-Morris M: Cytochrome P450 expression and metabolic activation of cooked food mutagen 2-amino-1methyl-6-phenylimidazo[4,5-b]pyridine (PhIP) in MCF10A breast epithelial cells. Chem Biol Interact 160: 204-216, 2006.

16. Duez P, Dehon G and Dubois J: Validation of raw data measurements in the comet assay. Talanta 63: 879-886, 2004

17. Ghoshal A, Preisegger K, Takayama S, Thorgeirsson S and Snyderwine E: Induction of mammary tumors in female Sprague-Dawley rats by the food-derived carcionogen 2-amino1-methyl-6-phenylimidazo[4,5-b]pyridine and effect of dietary fat. Carcinogenesis 15: 2429-2433, 1994.

18. Fan L, Schut H and Snyderwine E: Cytotoxicity, DNA adduct formation and DNA repair induced by 2-hydroxyamino-3methylimidazo[4,5-f]quinoline and 2-hydroxyamino-1-methyl6-phenylimidazo[4,5-b]pyridine in cultured human mammary epithelial cells. Carcinogenesis 16: 775-779, 1995.

19. Zhu J, Chang P, Bondy M, Sahin A, Singletary S, Takahashi S, Shirai T and Li D: Detection of 2-amino-1-methyl-6phenylimidazo[4,5-b]pyridine DNA adducts in normal breast tissues and risk of breast cancer. Cancer Epidemiol Biomarkers Prev 12: 830-837, 2003

20. Williams J and Phillips D: Mammary expression of xenobiotic metabolizing enzymes and their potential role in breast cancer. Cancer Res 60: 4667-4677, 2000.

21. Breen A and Murphy J: Reactions of oxyl radicals with DNA. Free Radic Biol Med 18: 1033-1077, 1995.

22. Allen R and Tresini M: Oxidative stress and gene regulation. Free Radic Biol Med 28 463-499, 2000.

23. Upham B and Wagner J: Toxicant-induced oxidative stress in cancer. Toxicol Sci 64: 1-3, 2001.
24. Schut $\mathrm{H}$ and Snyderwine E: DNA adducts of heterocyclic amine food mutagens: implications for mutagenesis and carcinogenesis. Carcinogenesis 20: 353-368, 1999.

25. Dubuisson $\mathbf{J}$ and Gaubatz J: Bioactivation of the proximal food mutagen 2-hydroxyamino-1-methyl-6-phenylimidazo[4,5-b] pyridine (N-OH-PhIP) to DNA binding species by human mammary gland enzymes. Nutrition 14: 710-712, 1998.

26. Lewis A, Walle U, King R, Kadlubar F, Falany C and Walle T: Bioactivation of the cooked food mutagen N-hydroxy-2-amino1 -methyl-6-phenylimidazo[4,5-b]pyridine by estrogen sulfotransferase in cultured human mammary epithelial cells. Carcinogenesis 19: 2049-2053, 1998.

27. Moonen H, Briede J, van Maanen J, Kleinjans J and de Kok T: Generation of free radicals and induction of DNA adducts by activation of heterocyclic aromatic amines via different metabolic pathways in vitro. Mol Carcinog 35: 196-203, 2002.

28. Creton S, Zhu H and Gooderham N: A mechanistic basis for the role of cycle arrest in the genetic toxicology of the dietary carcinogen 2-amino-1-methyl-6-phenylimidazo[4,5-b]pyridine (PhIP). Toxicol Sci 84: 335-343, 2005.

29. Roos W and Kaina B: DNA damage-induced cell death by apoptosis. Trends Mol Med 12: 440-450, 2006

30. Glaab W, Kort K and Skopek T: Specificity of mutations induced by the food-associated heterocyclic amine 2-amino-1-methyl-6phenylimidazo[4,5-b]pyridine in colon cancer cell lines defective in mismatch repair. Cancer Res 60: 4921-4925, 2001.

31. Huber W, McDaniel L, Kaderlik K, Teitel C, Lang N and Kadlubar F: Chemoprotection against the formation of colon DNA adducts from the food-borne carcinogen 2-amino-1methyl-6-phenylimidazo[4,5-b]pyridine (PhIP) in the rat. Mutat Res 376: 115-122, 1997.

32. Belloir C, Singh V, Daurat C, Seiss M and Le Bon A: Protective effects of garlic sulfur compounds against DNA damage induced by direct and indirect acting genotoxic agents in HepG2 cells. Food Chem Toxicol 44: 827-834, 2006. 